Virology Research Unit., Animal Reproduction Research Institute, Al-Haram, Giza, Egypt.

\title{
INFLUENCE OF BOVINE VIRAL DIARRHEA VIRUS INFECTION ON IN VITRO BUFFALO EMBRYOS PRODUCTION AND HISTOPATHOLOGICAL FINDINGS IN THEIR OVARIES
}

(With 3 Tables and 8 Figures)

By

\section{Y.G.M. ABD EL-HAFEIZ; M.R. BADR* and M.E. ESSMAIL**}

*AI and Embryo Transfer Department **Pathology of Reproduction Department, Animal Reproduction Research Institute, Al-Haram, Giza, Egypt. (Received at 13/12/2004)

تأثير فيروس الأسهال البقرى على انتاج ونمو أجنة الجاموس معمليا

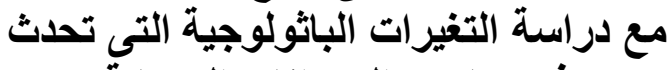
في مبايض الحيوانات المصابة البولية

ياسر جميل محمود عبل الحفيظ ، مجدى رمضان بلر ، محمد عبيل اسماعيل

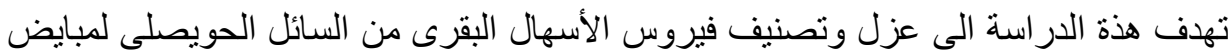

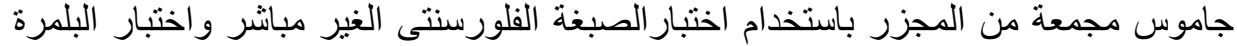

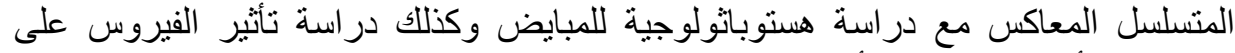

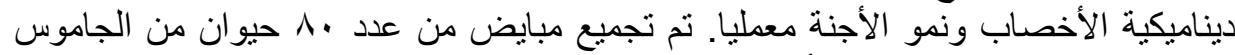

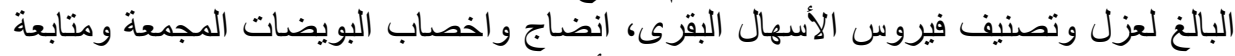

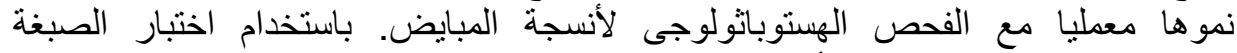

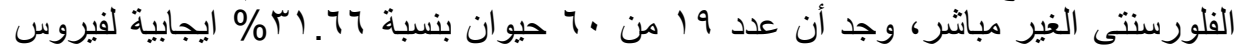

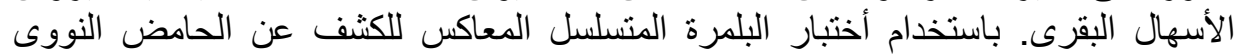

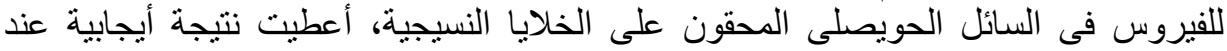

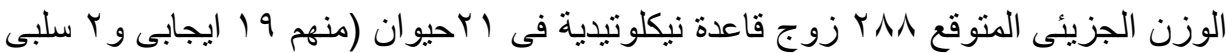

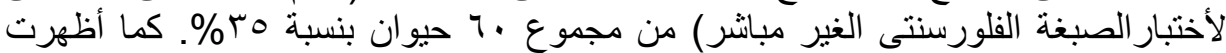

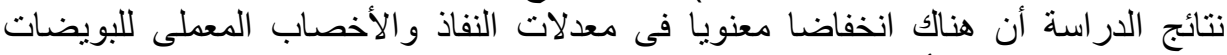

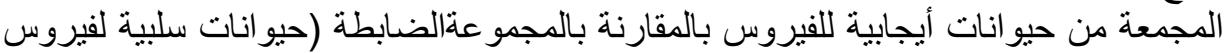

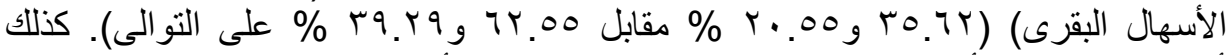

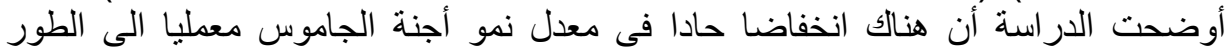

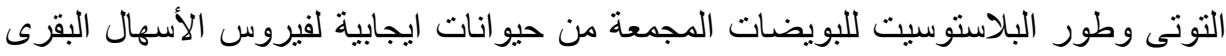

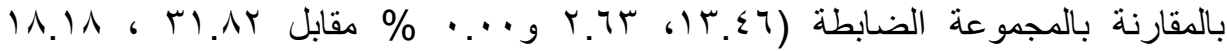

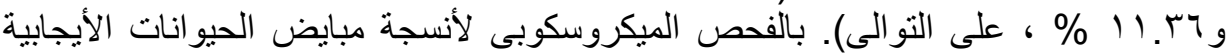


لفيروس الأسهال البقرى لوحظ أن هناك انخفاضا معنويا فى عدد الحويصلات (حويصلات

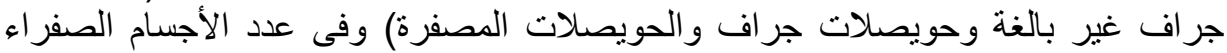

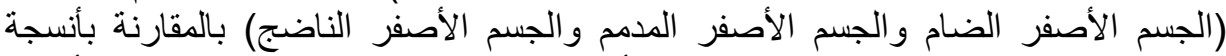

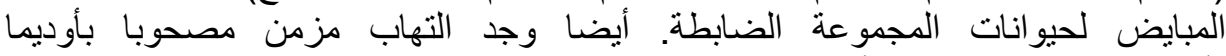

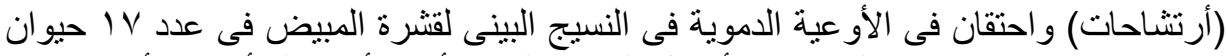

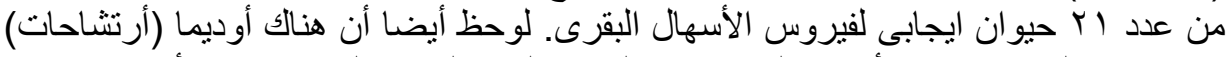

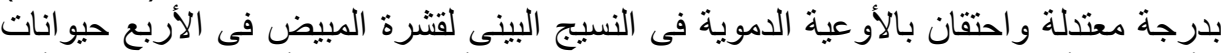

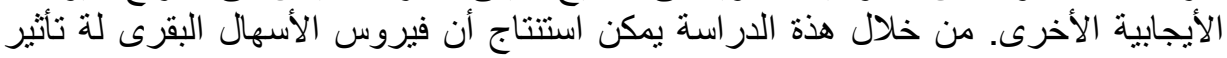

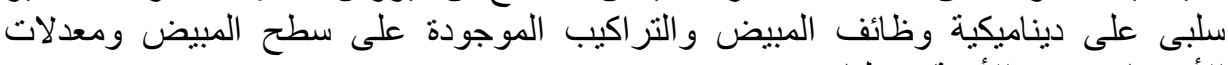
الأخصاب ونمو الأجنة معطليا.

\section{SUMMARY}

The objectives of this study were isolation and identification of bovine viral diarrhea virus (BVDV) from follicular fluid of buffalo ovaries by indirect immunofluoresence antibody technique (IFA) and reverse transcription-polymerase chain reaction (RT-PCR), histopathological findings as well as the effects of the virus on in vitro fertilization dynamics and embryos production system. Ovaries from 80 adult buffaloes were collected for BVDV isolation and identification, in vitro embryos production and histopathological study. Indirect immunofluoresence antibody technique revealed that 19 out of 60 animal $(31.66 \%)$ were positive. A PCR on inoculated follicular fluid gave a highly specific sharp bands at the expected molecular weight 288 bp in 21 animal (19 IFA positive and other 2 IFA negative samples)/60 $(35 \%)$. Bovine viral diarrhea virus infection caused a significance decrease $(\mathrm{P}<0.05)$ in the penetration and fertilization rates compared to the control (BVDV negative) group (35.62 and 20.55\% versus 62.50 and $39.29 \%$, respectively). Additionally, BVDV infection drastically reduced the cleavage rate, morula and blastocyst stages development $(13.46,2.63$ and $0.00 \%)$ as compared with the control $(31.82,18.18$ and $11.36 \%$, respectively). Microscopically, a significant reduction in the number of follicles (antral, graafian and luteinized) and corpora lutea (albican, hemorrhagicum and luteum) was noticed in ovaries of animals positive for BVDV as compared with the control. Also, chronic oophoritis was observed in 17 out of 21 animal positive for BVDV along with edema and congested blood vessels. Mild edema and congested blood vessels were noticed in the interstitial tissue of cortical stroma in the other 4 animals. In conclusion, this work debated that BVDV infection has great 
potential effects on ovarian dynamics, structures, in vitro fertilization and buffalo embryo development.

Key words: Bovine viral diarrhea, buffalo, embryo, ovary, histopathology.

\section{INTRODUCTION}

Bovine viral diarrhea virus (BVDV) belongs to the genus Pestivirus, family Flaviviridae (Francki et al., 1991). Bovine viral diarrhea virus paved for severe economic losses (Potgieter et al., 1984 and Harkness, 1987). It is a positive, single strand RNA of about 12.5 kilo base (kb) in length (Collett et al., $1988 \mathrm{a}$ and b and Rumenapf et al., 1993).

Pestiviruses are restricted to growth in cell culture of Artiodactyls, closely reflecting the in vivo host range (Doyle and Heuschele, 1983 and Nettleton, 1990). The effect of BVDV on bovine reproduction may be the most important consequence of infection. Many effects on reproduction have been documented, including infertility, early embryonic death, abortions and congenital defects (Grooms et al., 1998 a, b and c; Sheldon and Dobson, 2003 and Grooms, 2004). Since approximately 1-2\% of some national herds may be persistently infected (PI) with noncytopathic (NCP) strains (Fray et al., 2000) and in vitro embryos production system often use slaughterhouse tissues, virus transmission by embryos is a real risk (Bielanski et al., 1993; Bielanski, 1998 and Galik et al., 2002).

It has been shown that reproductive organs, including the ovaries, are one of the most predisposed sites for pestiviruses multiplication (Kirkland et al., 1992 and Brownlie et al., 1997). Bovine viral diarrhea virus has been isolated from the ovaries of cattle experimentally infected with BVDV (Ssentongo et al., 1980) and from follicular fluid (FF) of graafian follicles in ovaries derived from abattoirs (Bielanski et al., 1993). Moreover, previous studies have suggested that ovarian function may be changed in cattle acutely (Kafi et al., 1997) or PI with BVDV (Grooms et al., 1996).

Macrophage-like cells and their cytokines product have been shown to play important roles in ovarian function. Tumor necrosis factor- $\alpha$ (TNF- $\alpha$ ) and interleukin-1 (IL-1) have important effects on follicular growth and their differentiation. Changes in ovarian cytokine concentrations as a result of inflammation or disruption of ovarian macrophage function may lead to an interference with normal ovarian dynamics (Fukuoka et al., 1988; Adashi et al., 1989; Adashi, 1990; Kafi 
et al., 1997 and Grooms et al., 1998 a). Moreover, the presence of BVDV could conceivably alter in vitro embryonic development (Bielanski et al., 1993).

Pursing literatures of the last decade, the effect of BVDV infection on bovine fertility and reproduction performance received most of scientific attention. Some of the lesions are not BVDV specific, reflecting the limitation in tissue reactions, so laboratory diagnosis becomes an important (Fray et al., 2000 and Kim and Dubovi, 2003).

In Egypt, several studies have been focused on isolation and characterization of BVDV from cattle and buffaloes in different clinical samples after increased notification of BVD-MD outbreaks allover the country in spite of vaccination programs (Hafez, 1975; Abd El-Hafeiz, 1997; Hussein, 2001; Abd El-Hafeiz et al., 2003; Hassanein et al., 2003 and Abd El-Hafeiz, 2004). However, the association of BVDV with bovine reproductive system and in vitro embryos production system have been received a limited attention.

The objectives of the present study were isolation and identification of BVDV from $\mathrm{FF}$ on tissue culture by immunofluoresence antibody technique (IFA) and reverse transcriptionpolymerase chain reaction (RT-PCR), histopathological study of ovaries as well as studying the effects of the virus on the in vitro fertilization dynamics and embryo development of buffalo oocytes.

\section{MATERIALS and METHODS}

\section{Samples}

Ovaries of 80 adult buffaloes of unknown breeding history were collected from El-Hawamdia abattoir at Giza Province. All ovaries were examined morphologically and only those that having normal-looking follicles (60) were selected. Each pair of ovaries represented one animal. Follicular fluid containing oocytes was aspirated using 18 gauge needle attached to a $10 \mathrm{ml}$ sterile syringe from antral follicles $(2-8 \mathrm{~mm}$ in diameter) and released to a sterile microfuge tubes. After 10 minutes, the sediment was searched for oocytes and cumulus-oocytes complexes (COCs). The supernatant of FF was used for virus isolation and identification. The collected COCs were washed twice in Dulbecco's phosphate-buffered saline and once in tissue culture medium-199 (TCM199) with Earl's salt. Three separate tissue specimens from each ovary (represented the medial pole, middle portion and lateral pole) were selected for histopathological examination. 


\section{Viruses and cell culture}

Mycoplasma and BVDV-free Madin-Darby bovine kidney (MDBK) cells were supplied by (National Animal Diseases Center, Ames Iowa, USA). Eagle's minimum essential medium (MEM, Gibco, Life Technologies, Scotland, UK) supplemented with fetal bovine serum (FBS, Biochrom) and antibiotic/antimycotic (Sigma, Ames Iowa, USA) was used. An international NADL strain was used as a positive control all over virus isolation and identification.

\section{Virus isolation}

Virus isolation was performed on MDBK cell culture (Booth et al., 1995). Each FF sample was diluted 50\% v/v in MEM with 10\% FBS and cultured for 7 days/2 passages. Virus antigen was detected onto cover slip cultures by IFA technique using polyclonal anti-BVDV specific for reference strain NADL and anti-bovine IgG conjugated with fluorescence isothiocyanate (FITC).

\section{Extraction of RNA}

Intact RNA from all inoculated samples were extracted using a highly potent denature solution, acid guanidinium-phenol-chloroform method, as developed by Chomczynski and Sacchi (1987).

\section{Reverse transcription-polymerase chain reaction (RT-PCR)}

In two separate steps, reverse transcription (RT) and amplification of extracted RNA of each sample were done. By using Molony Murine Leukemia Virus-Reverse Transcriptase (MMLV-RT, Aßgene, UK) enzyme and hexameric primers (Promega, USA), RT of RNA was performed as described by the manufacturer (Aßgene, UK). Amplification of complimentary DNA (cDNA) by a primer sequence set within $5{ }^{\circ}$ untranslated region (5 UTR) as reported by Vilcek et al. (1994) and optimized PCR conditions as carried out by Abd El-Hafeiz (2004).

\section{Analysis of RT-PCR products}

Analysis of RT-PCR products was performed as in Weigand et al. (1993). The amplified products were mixed with 6X gel loading buffer (50\% sucrose, $2 \mathrm{mM}$ EDTA pH 8.0, 0.1\% bromo phenol blue, $0.1 \%$ xylene cyanole) $1: 5 \mathrm{v} / \mathrm{v}$ and electrophoresed through $1 \%$ agarose gel in tris-acetate-EDTA buffer containing $0.5 \mu \mathrm{g} / \mathrm{ml}$ ethidium bromide at 70 volts for 2 hours. After that, the amplified bands were visualized by UV transilluminator and photographed by a Polaroid camera.

\section{In vitro maturation (IVM) of oocytes}

All chemicals and hormones used to study the effects of BVDV infection on gametes were supplied from Sigma, Ames Iowa, USA. The maturation of oocytes was taken place as described by Stringfellow et al., 
2000. Oocytes from each buffalo-ovary in groups of 5-10, with compact multilayers and evenly granulated ooplasm were cultured in $50 \mu 1$ of TCM-199 supplemented with $10 \% \mathrm{FBS}$, sodium pyruvate $(50 \mu \mathrm{g} / \mathrm{ml})$, luteinizing hormone $(10 \mu \mathrm{g} / \mathrm{ml})$, follicle stimulating hormone $(5 \mu \mathrm{g} / \mathrm{ml})$, estradiol- $17 \beta(1 \mu \mathrm{g} / \mathrm{ml})$ and $50 \mu \mathrm{g} / \mathrm{ml}$ gentamycin sulfate and overlaid with a sterile paraffin oil. The cultured oocytes were incubated in a humidified atmosphere at $39^{\circ} \mathrm{C}, 5 \% \mathrm{CO}_{2}$ for 24 hours.

\section{Semen preparation and in vitro fertilization (IVF) of oocytes}

Frozen-thawed BVDV-free semen was pooled and used for IVF. The most motile spermatozoa were selected and prepared by a swim-up method according to Parrish et al. (1989). Briefly, aliquot of $100 \mu 1$ frozen-thawed semen was under layered $1 \mathrm{ml}$ sperm TALP (S-TALP) medium in 6 tubes and incubated at $38.5^{\circ} \mathrm{C}$ for one hour. After incubation, $400 \mu \mathrm{l}$ of the upper most layers were aspirated from each tube and pooled together in a clean sterile tube. The motile spermatozoa were centrifuged twice at $200 \mathrm{Xg}$ for 10 minutes and the supernatant was removed. The pellet was resuspended in fertilization medium (F-TALP) containing $25 \mu \mathrm{g} / \mathrm{ml}$ heparin for 30 minutes. The matured oocytes were washed three times in F-TALP medium prior to insemination with approximately $2 \times 10^{6}$ sperm cells/ml in fertilization drops and incubated at $39^{\circ} \mathrm{C}$ in $5 \% \mathrm{CO}_{2}$ for 18 hours (Bielanski and Jordan, 1996). In vitro embryo culture

As performed in Bielanski et al. (1993) and after IVF, the oocytes were freed from cumulus cells and extra sperms by repeated passage through a small-pore pipette and washed in the culture medium, TCM-199 with Hepes modification, (H-TCM-199). After washing, 5-10 presumptive zygotes were placed in each droplet of co-culture medium and incubated at $35^{\circ} \mathrm{C}, 5 \% \mathrm{CO}_{2}$ for 8 days. The cleavage rate was determined 48 hours after insemination. After 5-8 incubation days, the development to the morula and blastocyst stages was determined.

\section{Gross examination and histopathology}

All ovaries were examined grossly for recording the number of follicles and corpora lutea. Tissue specimens from each ovary were fixed in $10 \%$ neutral-buffered formalin and were routinely processed in an automated tissue processor, embedded in paraffin, sectioned at $5 \mu \mathrm{m}$, stained with hematoxylin and eosin (H\&E) and examined by light microscopy (Bancroft and Gamble, 2002).

Ovaries of 21 animal that were positive for BVDV isolation and those of 21 animal that were proved to be negative for BVDV isolation were compared microscopically concerning the pathological findings 
and the absolute number of the histological structures (antral, graafian, atretic, luteinized follicles and the corpus luteum/corpus albican/corpus hemorrhagicum) in the ovarian sections (3 sections/ovary).

Statistical analysis

The proportion of fertilized oocytes and those cleaved and developed to the morula and blastocyst stages were evaluated by Chisquare test $\left(\mathrm{X}^{2}\right)$. Different ovarian structures were evaluated by using Costat Computer Program, version 3.03, copyright (1986), Cottort Software, all data were subjected to analysis of variance (ANOVA). A probability of less than $0.05(\mathrm{P}<0.05)$ was considered statistically significant and less than $0.01 \quad(\mathrm{P}<0.01)$ was considered statistically highly significant.

\section{RESULTS}

\section{Virus isolation and identification}

In this study, FF samples (60) propagated successfully on inoculated cells. By using IFA technique, fluorescence granules were distributed as perinuclear, intracytoplasmic and at nuclear pools in 19 out of 60 inoculated samples $(31.66 \%)$ as in positive control (Fig.1). Negative control included in this study showing no fluorescence granules. By using MMLV-RT enzyme, Taq polymerase and a primer sequence set within 5 UTR, 21 RNA samples (19 IFA positive and other 2 IFA negative) as well as the positive control (NADL strain) were reverse transcriped and amplified and gave sharp bands at the expected size 288 bp. A negative control was not amplified (Fig.2).

\section{The effect of BVDV on in vitro fertilization rate and embryonic development}

As presented in Tables 1 and 2, BVDV infection caused drastic significance decrease $(\mathrm{P}<0.05)$ in the penetration and fertilization rates compared to the control group (35.62 and 20.55\% versus 62.50 and $39.29 \%$, respectively) (Fig.3). Additionally, BVDV infection drastically reduced the cleavage rate, morula and blastocyst stages development $(13.46,2.63$ and $0.00 \%)$ as compared with the control $(31.82,18.18$ and $11.36 \%$ ), respectively (Fig.4). 
Table 1: Influence of BVDV infection on in vitro penetration and fertilization rates of buffalo oocytes.

\begin{tabular}{|c|c|c|c|c|}
\hline & No. of oocytes & Penetration rate & Fertilization rate & Polyspermy \\
\hline & & No. & No. $\%$ & No. $\%$ \\
\hline $\begin{array}{l}\text { Control } \\
\text { (BVDV free) }\end{array}$ & 56 & $35 \quad(62.50)^{\mathrm{a}}$ & $22(39.29)^{\mathrm{a}}$ & $3(5.36)^{\mathrm{a}}$ \\
\hline BVDV (+ve) & 73 & $26(35.62)^{b}$ & $15(20.55)^{b}$ & $5(6.85)^{\mathrm{a}}$ \\
\hline
\end{tabular}

Values with different letters in the same column were significantly different $(\mathrm{P}<0.05)$.

Table 2: Influence of BVDV infections on in vitro embryos development.

\begin{tabular}{|c|c|c|c|c|}
\hline & $\begin{array}{c}\text { No. of inseminated } \\
\text { oocytes }\end{array}$ & $\begin{array}{l}\text { Cleavage rate } \\
\text { No. } \%\end{array}$ & \begin{tabular}{c}
\multicolumn{2}{r}{ Morula } \\
No. $\%$ \\
\end{tabular} & $\begin{array}{l}\text { Blastocyst } \\
\text { No. \% }\end{array}$ \\
\hline $\begin{array}{l}\text { Control } \\
\text { (BVDV free) }\end{array}$ & 44 & $14(31.82)^{\mathrm{a}}$ & $8(18.18)^{a}$ & $5(11.36)^{\mathrm{a}}$ \\
\hline BVDV (+ve) & 38 & $5 \quad(13.46)^{b}$ & $1 \quad(2.63)^{b}$ & $0(0.00)^{\mathrm{a}}$ \\
\hline
\end{tabular}

Values with different letters in the same column were significantly different $(\mathrm{P}<0.05)$.

\section{Pathological findings}

Grossly, ovaries from animals that were positive for the BVDV isolation had a fewer number of follicles and corpora lutea as compared with the ovaries from animals that were negative for BVDV isolation.

Microscopically, the number of antral and luteinized follicles was highly significant lower $(\mathrm{P}<0.01)$ in the buffalo ovaries that were positive for BVDV isolation (Table 3). The number of graafian follicles and corpora lutea was significantly lower $(\mathrm{P}<0.05)$ in the buffalo ovaries that were positive for BVDV isolation.

The pathological changes observed in the ovarian sections from animals that were positive for BVDV isolation (21animal) were characteristic for chronic oophoritis in 17 out of the 21 animal and represented by presence of mononuclear cells (mostly plasma cells and /or lymphocytes and few histiocytes) along with edema and congested blood vessels in the interstitial tissue of cortical stroma (Figs. 5, 6, 7 and 8). However, infiltration of the interstitial tissue of cortical stroma with the mononuclear inflammatory cells was ranged from mild (in 4/17 animal) to marked (in 13/17 animal). Only mild edema and congested 
blood vessels in the interstitial tissue of cortical stroma were noticed in 4 animals out of 21 animal positive for BVDV isolation. Ovaries of animals that were negative for BVDV isolation showed no significant pathological changes except mild edema in the interstitial tissue of cortical stroma in 2 animals.

Table 3: Rate of ovarian structures per total number of positive and negative BVDV cases.

\begin{tabular}{|c|c|c|}
\hline Ovarian structure & BVDV $+($ Mean \pm SE) & $\begin{array}{l}\text { Control (Mean } \pm \text { SE) } \\
\text { (BVDV free) }\end{array}$ \\
\hline Antral follicles & $(27 \pm 2.00)^{\mathrm{a}}$ & $(57 \pm 3.61)^{\mathrm{b} * *}$ \\
\hline Graafian follicles & $(19 \pm 2.09)^{\mathrm{a}}$ & $(31 \pm 2.65)^{\mathrm{b} *}$ \\
\hline Luteinized follicles & $(12 \pm 1.53)^{\mathrm{a}}$ & $(24 \pm 2.08)^{\mathrm{b}}$ \\
\hline Atretic follicles & $(16 \pm 2.51)^{\mathrm{a}}$ & $(25 \pm 2.64)^{\mathrm{a}}$ \\
\hline Corpora lutea & $(15 \pm 3.51)^{\mathrm{a}}$ & $(26 \pm 1.56)^{\mathrm{b}}$ \\
\hline
\end{tabular}

Values with different superscripts in the same row were significantly different at $\mathrm{P}<0.05$ and highly significant at $\mathrm{P}<0.01$.

$* \mathrm{P}<0.05 \quad * * \mathrm{P}<0.01 \quad$ Data expressed as $\mathrm{M} \pm \mathrm{SE}$.

\section{DISCUSSION}

Diagnostic techniques using IFA and RT-PCR were developed for detection of both viral antigens and genomes in different clinical samples from BVDV carriers. Using anti-BVDV reference strain NADL and FITC conjugated anti-bovine IgG in IFA as a preliminary test for screening the inoculated FF on MDBK cells revealed that 19 out of 60 animal $(31.66 \%)$ were positive for BVDV. Fluorescence granules distributed perinuclear, intracytoplasmic and at nuclear pools in early incubation were seen as previously reported by Donis et al. (1988). The distribution of viral antigens is most consistent with its localization in the rough endoplasmic reticulum ( $\mathrm{Ng}$ et al., 1983). Reverse transcription-polymerase chain reaction is an in vitro technique that is increasingly being used for diagnosis of viral animal pathogens. Due to its high sensitivity, it is considered as an alternative to currant standard methods for detecting BVDV especially in pooled samples. A PCR 
oligonucleotide primer set was chosen in 5 UTR that is one of the highest conserved regions among BVDV strains. Within this region, the homology percentage is higher between different strains in genotype 1, either cytopathic or noncytopathic, can reach to 86-93\% (Deng and Brock, 1992) and about 95\% between genotypes 1and 2 (Ridpath and Bolin, 1995).

In this study, PCR on inoculated follicular fluid gave highly specific sharp bands at the expected molecular weight 288 bp in 21 animal (19 IFA positive and other 2 IFA negative samples)/60 (35\%). The NADL strain, as positive control, gave a sharp band at the same molecular weight while the mock infected cellular RNA was not amplified. The current results demonstrated that PCR is more sensitive in the detection of BVDV than IFA.

The present study emphasizes that the BVDV infection reduced drastically IVF and embryonic development in buffalo. These results are in agreement with Bielnski and Dubuc (1993) and Stringfellow et al. (2000) who found that the presence of noncytopathic BVDV can result in reduced rates of fertilization and development. They added that the reduction was more dramatic when the virus was associated with gametes derived from infected animals than in vitro infection of gametes and no significant difference in development was observed. Moreover, specific association of BVDV with FF, cumulus cells and even with oocytes from acutely or PI heifers has been reported (Booth et al., 1992; Avery et al., 1993; Bielanski et al., 1993; Booth et al., 1995 and Fray et al., 1998). Thus, the pooling of cumulus cells and aspiration of FF from follicles on ovaries derived from abattoirs provide an opportunity to amplify the virus (Strigfellow et al., 2000).

Chronic oophoritis that noted in animals positive for BVDV was in accordance with the finding of Ssentongo et al. (1980) who described chronic oophoritis in cattle following the acute infection with BVDV. The reduction of histological structures (antral, graafian, atretic and luteinized follicles and corpus luteum/corpus albican/corpus hemorrhagicum) in the ovarian sections from animals that were positive for BVDV was in agreement with the findings of Grooms et al. (1996) in the PI cattle with BVDV. They mentioned that the reduced number of follicles and corpora lutea in the BVDV positive animals may indicate altered ovarian function due to chronic oophoritis. On the other hand, Gottschall et al. (1987), Emoto and Baird (1988), Fukuoka et al. (1988), Darbon et al. (1989), Dinarello (1989) and Adashi (1990) added that chronic oophoritis could result in changes in ovarian cytokine 
concentrations (local regulators of ovarian function) that responsible, in part, for the disruption of ovarian function during the chronic infection with BVDV. Moreover, Kafi et al. (1997) suggested that BVDV could affect the feed-back mechanisms originating from the ovary that help the release of both $\mathrm{FSH}$ and $\mathrm{LH}$.

Finally, this work debated the effects of BVDV infection on ovarian structures and on in vitro embryos production system and indicated that BVDV infection has great potential effects on ovarian dynamics, structures, IVF and buffalo embryo development. More studies must argue the other reproductive problems and their association with BVDV infection.

\section{REFERENCES}

Abd El-Hafeiz, Y.G.M. (1997): Trial to use molecular biology technique for genotyping the Egyptian strains of BVD viruses. M.V.Sc., Thesis, Fac.Vet. Med., Cairo Univ.

Abd El-Hafeiz, Y.G.M.; Hussein, H.A.; Amin, A.S. and Reda, I.M. (2003): Current status of BVDV in Egypt: Isolation, antigenic and genetic characterization of cytopathic and noncytopathic stains of genotype 2 from milk. $7^{\text {th }}$ Sci. Cong., Egyptian Society for cattle diseases, 7-9 Dec. 2003, Assiut, Egypt.

Abd El-Hafeiz, Y.G.M. (2004): Isolation and identification of bovine viral diarrhea virus in semen samples. Assiut Vet. Med. J. 50 (103): 188-198.

Adashi, E.Y. (1990): The potential relevance of cytokines to ovarian physiology: The emerging role of resident ovarian cells of the white blood cell series. Endocrine Rev. 11: 454-464.

Adashi, E.Y.; Resnick, C.E.; Croft, C.F. and Payne, D.W. (1989): Tumor necrosis factor- $\alpha$ inhibits gonadotropin hormonal action in nontransformed ovarian granulosa cells. J. Biol. Chem. 264: 11591-11597.

Avery, B.; Greve, T.; Ronsholt, L. and Botner, A. (1993): Virus screening of a bovine in vitro embryos production system. Vet. Rec. 132: 660

Bancroft, J.D. and Gamble, M. (2002): Theory and Practice of Histological Techniques. $5^{\text {th }}$ edition, Churchill livingstone, London, Edinburgh, New York, Philadelphia, St. Louis, Sydney, Toronto. 
Bielanski, A. (1998): Potential for disease control or transmission by embryos produced in vitro: A review of current literature. In: Stringfellow, D.A. and Seidel, S.M. (eds.), Manual of the International Embryo Transfer Society. Savoy IL: IETS, 45-53.

Bielanski, A. and Dubuc, C. (1993): In vitro fertilization of ova from cows experimentally infected with a noncytopathic strain of bovine viral diarrhea virus. Anim. Reprod. Sci. 38: 215-221.

Bielanski, A. and Jordan, L. (1996): Washing or washing and trypsin treatment is ineffective for removal of noncytopathic bovine viral diarrhea virus from bovine oocytes or embryos after experimental viral contamination of an in vitro fertilization system. Theriogenology, 46: 1467-1476.

Bielanski, A.; Loewen, K.S.; DelCamp, M.R.; Sirard, M.A. and Willadsen, S. (1993): Isolation of bovine herpes virus-1 (BHV1) and bovine viral diarrhea virus (BVDV) in association with the in vitro production of bovine embryos. Theriogenology, 40: 531-538.

Booth, P.J.; Stevens, D.A.; Collins, M.E. and Brownlie, J. (1992): Detection of bovine viral diarrhea virus (BVDV) in ovarian and oviductal tissue. J. Reprod. Fertil. Abst. No. 928.

Booth, P.J.; Stevens, D.A.; Collins, M.E. and Brownlie, J. (1995): Detection of bovine viral diarrhea virus antigen and RNA in oviduct and granulosa cells of persistently infected cattle. J. Reprod. Fertil. 105: 17-2.

Brownlie, J.; Booth, B.J.D.; Stevens, D.A. and Collins, M.E. (1997): Expression of noncytopathogenic bovine viral diarrhea virus (BVDV) in oocytes and follicles of persistently infected cattle. Vet. Rec. 141: 335-337.

Chomczynski, P. and Sacchi, N. (1987): Single-step method of RNA isolation by acid guanidinium thiocyanate-phenol-chloroform extraction. Analy. Biochem. 162: 156-159.

Collett, M.S.; Larson, R.; Belzer, S.K. and Retzel, E. (1988 a): Proteins encoded by bovine viral diarrhea virus: The genomic organization of a pestivirus. Virol. 165: 200-20.

Collett, M.S.; Larson, R.; Gold, C.; Strick, D.; Anderson, D.K. and Purchio, A.F. (1988 b): Molecular cloning and nucleotide sequence of the pestivirus: bovine viral diarrhea virus. Virol. 165: 191-199.

Costat Computer Program (1986): Version 3.03, copyright Software. 
Darbon, J.M.; Oury, F.; Laredo, J. and Bayard, F. (1989): Tumor necrosis factor- $\alpha$ inhibits follicle-stimulating hormone-induced differentiation in cultured rat granulose cells. Biochem. Biophy. Res. Com. 163: 1038-1046.

Deng, R. and Brock, K.V. (1992): Molecular cloning and nucleotide sequence of a pestivirus genome, noncytopathic bovine viral diarrhea virus strain SD-1. Virol. 191: 867-879.

Dinarello, C.A. (1989): Biology of interleukin1. FA S E B, 2: 108-115.

Donis, R.O.; Corapi, W. and Dubovi, E.J. (1988): Neutralizing monoclonal antibodies to bovine viral diarrhea virus bind to the $56 \mathrm{k}$ to $58 \mathrm{k}$ glycoprotein. J. Gen. Virol. 69: 77-86.

Doyle, L.E. and Heuschele, W.P. (1983): Bovine viral diarrhea virus infection in captive exotic ruminants. J. Am. Vet. Med. Assoc. 183: $1257-1259$.

Emoto, N. and Baird, A. (1988): The effect of tumor necrosis factor/cochectin on follicle stimulating hormone induced aromatase activity in cultured rat granulosa cells. Biochem. Bioph. Res. Com. 153: 792-798.

Francki, R.I.B.; Fauquet, C.M.; Knudson, D.L. and Brown, F. (1991): Classification and nomenclature of viruses: Fifth report of the international committee on taxonomy of viruses. Arch. Virol. Suppl. 2: 223-233.

Fray, M.D.; Paton, D.J. and Alenius, S. (2000): The effects of bovine viral diarrhea virus on cattle reproduction in relation to disease control. Anim. Reprod. Sci. 2; 60-61: 615-627.

Fray, M.D.; Prentice, H.; Clarke, M.C .and Charleston, B. (1998): Immunohistochemical evidence for the localization of bovine viral diarrhea virus, a single-stranded RNA virus, in ovarian oocytes in cow. Vet. Pathol. 35: 253-259.

Fukuoka, M.; Takahide, M.; Taii, S. and Yasuda, K. (1988): Interleukin1 inhibits luteinization of porcine granulosa cells in culture. Endocrinology, 122: 367-369.

Galik, P.K.; Givens, M.D.; Stringfellow, D.A.; Crichton, E.G.; Bishop, M.D. and Eilertsen, K.J. (2002): Bovine viral diarrhea virus (BVDV) and anti-BVDV antibodies in pooled samples of follicular fluid. Theriogenology, 57 (4): 1219-1227.

Gottschall, P.E.; Uehara, A.; Talbot Hoffman, S. and Armura, A. (1987): Interleukin-1inhibits follicle stimulating induced differentiation in rat granulosa cells in vitro. Biochem. Biophy. Res. Com. 149: 502-509. 
Grooms, D.L. (2004): Reproductive consequences of infection with bovine viral diarrhea virus. Vet. Clin. North Am. Food Anim. Pract. 20 (1): 5-19.

Grooms, D.L.; Brock, K.V. and Ward, L.A. (1998 a): Detection of bovine viral diarrhea virus in the ovaries of cattle acutely infected with bovine viral diarrhea virus. J. Vet. Diag. Invest. 10: 125-129.

Grooms, D.L.; Brock, K.V. and Ward, L.A. (1998 b): Detection of cytopathic bovine viral diarrhea virus in the ovaries of cattle following immunization with a modified live bovine viral diarrhea virus vaccine. J. Vet. Diag. Invest. 10: 130-134.

Grooms, D.L.; Brock, K.V.; Pate, J.L. and Day, M.L. (1998 c): Changes in ovarian follicles following acute infection with bovine viral diarrhea virus. Theriogenology, 49: 595-605.

Grooms, D.L. Ward, L.A. and Brock, K.V. (1996): Morphological changes and immunehistochemical detection of viral antigen in ovaries from cattle persistently infected with bovine viral diarrhea virus. Am. J. Vet. Res. 57 (6): 830-833.

Hafez, S.M. (1975): Isolation and identification of bovine viral diarrheamucosal disease virus in Egypt. Egypt. J. Vet. Med. Assoc. 35(1):1-9.

Harkness, J.W. (1987): The control of bovine viral diarrhea virus infection. Ann. de Res Vet. 18: 167-174.

Hassanein, S.A.; Hussein, H.A.; Karim, I.A.; Reda, I.M. and Shalaby, M.A. (2003): Current status of BVDV in Egypt: 2. Isolation, antigenic and genomic characterization of BVDV genotype 1 and 11 from calves in Egypt. J. Egypt.Vet. Med. Assoc. 63 (5): 399- 415.

Hussein, A.H. (2001): Molecular characterization of the Egyptian strain (Iman) of BVDV and its RNA synthesis in cell culture. Arab. J. Biotech. 4 (1): 23-36.

Kafi, M.; McGowan, M.R.; Kirkland, P.D. and Jillella, D. (1997): The effect of bovine pestivirus infection on the superovulatory response of Frisian heifers. Theriogenology, 48: 996-996.

Kirkland, P.D.; McGowan, M.R. and Machintosh, S.G. (1992): Factors influencing the development of persistent infection of cattle with pestivirus. In: Proceeding of the second symposium on pestiviruses. Anecy, France, pp., 117-121. 
Kim, S.G. and Dubovi, E.J. (2003): A novel simple one-step, single tube RT-duplex PCR method with an internal control for detection of bovine viral diarrhea virus in bulk milk, blood and follicular fluid samples. Biologicals, 31 (2): 103-106.

Nettleton, P.F. (1990): Pestivirus infections in ruminants other than cattle. Rev. Sci. Tech. Off. Inter. Des Epiz. 9: 131-150.

Ng, M.L.; Pedersen, J.S.; Toth, B.H. and Westaway, E.G. (1983): Immunoflurosence sites in Vero cells infected with the flavivirus kunjin. Arch. Virol. 78: 177- 190.

Parrish, G.G.; Susko-Parrish, G.L. and First, N.L. (1989): Capacitation of bovine sperm by heparin: Inhibitory effect of glucose and role of intracellular pH. Biol. Reprod. 41: 683-699.

Potgieter, L.N.D; McCracken, M.D.; Hopkins, F.M.; Walker, R.D. and Guy, J.S. (1984): Experimental production of bovine respiratory tract disease with bovine viral diarrhea virus. Am. J. Vet. Res. 45 (80): 1582-1585.

Ridpath, J.C. and Bolin, S.R. (1995): The genomic sequence of a virulent bovine viral diarrhea virus (BVDV) from the genotype 2: detection of a large genomic insertion in a noncytopathic BVDV. Virol. 212: 39-46.

Rumenapf, T.; Unger, G.; Strauss, J.H. and Thiel, H-J. (1993): Processing of the envelope glycoproteins of pestiviruses. J. Virol. 67 (6): 3288-3294.

Sheldon, I.M. and Dobson, H. (2003): Reprodutcive challenges facing the cattle industry at the beginning of the $21^{\text {st }}$ century. Reprod. Suppl. 61: 1-13.

Ssentongo, Y.K.; Johnson, R.H. and Smith, J.R. (1980): Association of bovine viral diarrhea-mucosal disease virus with ovaritis in cattle. Aust. Vet. J. 56: 272-273.

Strigfellow, A.D.; Riddell, K.P.; Galik, P.K.; Damiani, P.; Bishop, M.D. and Wright, J.C. (2000): Quality controls for bovine viral diarrhea virus-free IVF embryos. Theriogenology, 53: 827-839

Vilcek, S.; Herring, A.J.; Herring, J.A.; Nettleton, P.F.; Lowings, J.P. and Paton, D.J. (1994): Pestiviruses isolated from pigs, cattle and sheep can allocated into at least three geno groups using polymerase chain reaction and restriction endonuclease analysis. Arch. Virol. 136: 309-323.

Weigand, F.; Baum, M. and Udupa, S. (1993): DNA molecular marker techniques: Technical manual No.20 International Center for 
Assiut Vet. Med. J. Vol. 51 No. 104 January 2005

Agriculture Research in the Dry Area (ICARDA), Aleppo, Syria. 
Fig. 1: BVDV-free MDBK cells in inoculated with follicular fluid and stained with polyclonal anti-BVDV followed by FITC conjugated anti-bovine IgG. Intracytoplasmic fluorescence granules were seen perinuclear and at nuclear pools (arrows) (X 200)

Fig. 2: Agarose gel (1\%) analysis of RT-PCR amplified products of 5 UTR viral RNA: M is 50 bp DNA ladder (Promega, Cat. No. G 4521). Lane I is a positive control (NADL strain), lanes 2, 3, 5 and 6 are some represented positive samples and lane 7 is a negative control.

Fig. 3: Microphotograph of fertilized BVDV-free buffalo oocyte showing male and female pronuclei formation. (X 40).

Fig. 4: Microphotograph of BVDV-free buffalo oocyte developed in vitro to blastocyst stage. (X 40).

Fig. 5: Ovary positive for BVDV isolation showing marked infiltration of the interstitial tissue of the cortical stroma with plasma cells and few lymphocytes (H\&E, X100).

Fig. 6: Ovary positive for BVDV isolation showing marked infiltration of the interstitial tissue of the cortical stroma with plasma cells along with marked edema (H\&E, X 400).

Fig. 7: Ovary positive for BVDV isolation showing marked edema, congested blood vessels, and mild lymphocytic infiltration in the interstitial tissue of the cortical stroma (H\&E, X 100).

Fig. 8: Ovary positive for BVDV isolation showing marked edema, congested blood vessels, and plasma cells infiltration in the interstitial tissue of the cortical stroma (H\&E, X 400) 
Assiut Vet. Med. J. Vol. 51 No. 104 January 2005 